\title{
To Start Again: Putting "The New Life" in Perspective - Mark Halperin
}

VERN RUTSALA has published five volumes of poetry whose difficulties have little to do with esoteric reference or complex surfaces. In his work one can miss what's happening, particularly in recent poems, because they are often quiet; it takes a second or third reading to begin to hear them. Additionally, Rutsala avoids the transcendent. Rarely does the speaker in a poem attain joy or even joyous insight. It's far more likely he'll hanker after meaning; his state is apt to be wary and infused with guilt or fear. That might lead one to expect a static world, but Rutsala's work deals with recurrent though constantly different problems, and what recapitulations occur always occur on a new plane.

The poems in The New Life (Trask House, Portland 1978) tell the story clearly. There are ten, mostly a page or two long, with the last one longer, all this typical of Rutsala. One way to read this book is to consider it to be made up of two sequences, two arcs, the first of which runs through a poem called "The Journey Home." That journey is one we reach by stages. The book opens with one of Rutsala's "state" poems (more on this later). A speaker, dissociated from himself, an everyman, "you," has arrived in the land of dust which is referred to as a "desert." His journey has been away from a familiar landscape of loss into one that points to age:

Everything ground to powder. The body knows.

Bones pulverized

to make the flour that makes the bread

the giant eats.

In "The Shack Outside Boise," the "you" takes on more individualized characteristics, the place a determinate one; more of the world has entered. Sadness is linked to possessions, others-particularly family, though not immediate family. The scene is more communal: "they divide it up / making sure you get your fair share."

It takes these two poems and the process of solidification they provide to reach the first magical poem of the volume, "The World." Here the speaker has become an "I," his journey "by shortcut and dream. I fly above / it all." We experience a lovely, imagined return to the speaker's childhood, though without others and only as a landscape. The remarkable aspect of the poem is how clearly it demonstrates the kind of success possible in a Rutsala poem. There's a fusion of speaker and imaginative act; we follow the speaker's attempt to invent: "my own way back, invent / these wings." We see the town "where the land tastes bad, / where dust even slips / under rich men's doors." What we're not prepared for is the turn that makes present past and past present. Here's the last sentence: 


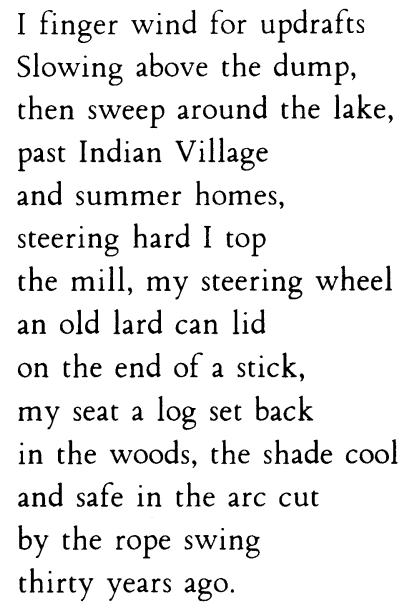

The lard can lid is the integrating image; the action of the imaginer and the object of the child are the same.

Moves like that seem to me terribly quiet. The speaker finally refuses to let me stay in the world he has reached by stressing his own distance from it. To take it back is doubly amazing.

In "American Dream" and "On A Binge With Dakota Slim," which follow, the ear and hearsay aid the imagination on its journey. In the first, the past is resurrected in discarded objects; in the second, the speaker fuses with Dakota Slim, the first "person" to enter the poems, a loser though full of energy. In this latter piece, the world is truly present in abundance: radio static from Boise, razor keen knives. Finally, it's

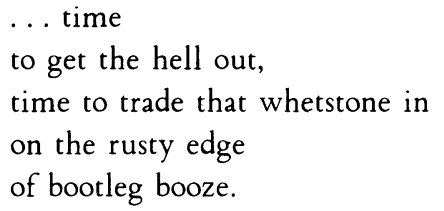

Again the disparate collection is sewn together precisely with that "rusty edge." There's humor at the same time that a hopeless situation is left to stand. Temporary escapes exist as such in booze and sleep.

Finally, completing the arc, "The Journey Home" has a speaker talking of a "you" dressed in the costume of failure: "cardboard shoes, in a thin / Cheap jacket, in a hat / without shape." There is an abstract series - funeral, grief and healing - and a house image (the image Rutsala returns to again and again in the course of his writing); this is childhood and origin seen with the bleakness of loss. The past has a locked door. But the "you" pounds and pounds. And the pounding does not go unanswered. 
The second sequence in The New Life takes us through that door to family, father and grandmother, framing it, attempting to reconstruct it, to hear its odd music. "Washrags" is my favorite, perhaps the best poem in the book. It looks for history and finds heritage. The old country of the Finns comes with them to Long Valley where it destroys their lives:

they lugged it with them

It was a millstone and the knives in their boots

... They took it to dances

Condensed and distilled

In pint bottles

They beat each other with it

Behind Finn Hall.

They have an explanation for everything, but one that leaves things as they are; and the speaker covertly recognizes he carries it with him. In a device so transparent we don't notice, the poem has been built on a series of what seem appositives. When we have forgotten the first, the old country, we remember only Long Valley which the "its" have generated. It is a heritage, finally, that can't be buried though the speaker ends:

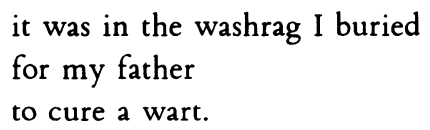

The theme of The New Life may be pointed to in "Building the House," the house image being a tip-off.

Out of nothingness and shadow

I try to build it up again.

I begin with kindling

and mill ends. I use

the cardboard tools of memory.

The speaker succeeds only to "enter and meet / the cold music of empty rooms." Still, that is a music. Memory may be no answer, but it is a task to accomplish. Starting with the terrible distance we begin in and ending with "Visiting Day" where an old woman is addressed: "all for you. All for you. / We have done what we can," another world is produced successfully.

A measure of the progress in Rutsala's poetry can be gauged by his titles (in the following discussion I have left out Paragraphs, a volume of prose poems): The Window (Weslyan University Press 1964), Laments (New Rivers Press, 1975), The Journey Begins 
(The University of Georgia Press, 1976) and The New Life. There is no linear development; rather these are stages of "re-vision." Memory is a task. Borges says, "each writer creates his precursors. His work modifies our conception of the past, as it will modify the future." The reading I propose of Rutsala's work comes then not only from the prejudices of my taste, but from the shadows each of his volumes casts on its successors and, at least as much, the light each volume casts on its precursors.

In The Window we view a world often terrifying and even more often leached out by ennui. The best poems seem dismayingly honest, which makes their negative assessments the more hopeless. The characteristic stance is one of passivity. Something is wrong; we don't know why. The speaker, talking of "we," "you" or "I," or being omniscient, is cut off from the world. Disaffected, alienated, he views from his window. In Laments a journey begins, down and thus away from the glass. Reactions appear, often negative, but they depend on outward identifications. The speaker has chosen losers, the variously disenfranchised. He laments what has happened to them more than who they are. By the end of The Journey Begins, we are aware of further change. Again, starting from "dis-ease," the speaker has projected himself into the lives of others, picked out his part; this time he has joined them by compassion, a word the speaker in the closing poem "Drinking Late," disparages:

It shows one's humanity, every one saying,

"Look how open and honest he is."

I see the dead evening this way, how so many spin out the sticky nets of their compassion. But the mesh is wide...

There is something much less egocentric about this volume. Finally, in The New Life, a new life has begun, the old one to be sure, revisited, but with new eyes.

In a sense, all the volumes after the first-and there are abundant hints of a desire to move on there too-are voyages, none staisfactory, all attempts to enter the world more fully. The earlier poems are full of comments that tend toward the revelation of emotional states. The later poems divest themselves of comment and yet make statements because of their ability to embody their attitudes.

Stylistically, Rutsala's poems fall into two basic types. I've alluded to one, the "generalized" emotion state poem. These begin by mentioning the time of day and then move through catalogues of objects, before or near the speaker, to explore an emotion. Early poems of this sort speak about meaning or its absence. They operate with a large number of abstract terms which refer to emotional and moral conditions and yoke these into the poem by an "of" formula as the following examples demonstrate: "Fears" (TW), "the feather boa of their innocence"; "Review" (TW), "I see again / how the usual aimless beads / of action were strung on the knotted twine of time." Such poems can be moving while almost mute. They point to inactivity as a problem that ends up faceless, and indescribable. 
The second type of poem concentrates on scene or narrative (or combines both), embodying its emotions by becoming numinous. We need no interpretation because scene or action speaks for itself. To take an early example, "Listening" (TW) presents an apartment house filled with other lives, possibilities that turn out to be no different from the speaker's:

Next door, locked behind a fear of sudden thunder, a child draws stick figures of his absent parents and then with cries tears them to confetti.

I've quoted sections from poems in The New Life that also exemplify this possibility.

The ratio of abstract (state) poems to concrete (numinous) poems has been shifting in favor of the latter in Rutsala's work. But I don't want to leave the impression that better editing would have freed Rutsala from writing the former. My terms are loaded; the state his speakers try so hard to locate and describe is only locatable as a world becomes available. And there are abstract "state" poems, as I've divided them up, that are among the best in The Window (I think this has to be the case). One of my favorites, "Playground," starts off with a description that veers toward the surreal, after which a catalogue of children appears:
the cheat, quick hands
making ready
for a future of short
change; the liar
practices his surgery
on the real.

The poem ends, set in a sports metaphor established earlier:
The lovers and the doomed
grow tan, and the good
are somehow learning
the punishing arts
of their losing game.

Another fine poem in this volume, "The Poet at Twenty Seven," locates part of what I've been talking about this way: "I think of the bald eloquence / events all have that words must steal." It is a poem suffused with underwater imagery of the sort Rutsala links to something deep within, an area of imagination of childhood freedom, healing and very dangerous to court. To add to my list of favorites there are: "Five O'Clock 
Meditation," "A Day in March," "Today Is Monday," "The Spare Room," and the most ambitious, if not quite successful, poem that attempts to deal with the conflict between private and public responsibilities, "Gilbert and Market."

Laments, I have said, attempts to journey past the stultifying present. At first reading nothing of the sort seems involved; speakers appear to indulge themselves in regret. But in the key first poem, "An Answer," this relationship to the voiceless is made:

\author{
The blunted \\ and thwarted live. \\ Each glance that met \\ stone, each word \\ that looked for \\ an echo finds \\ its place.
}

If the task of The Window was to experience loss without location, specification comes in the new volume. Rather than meditations we get ostensible subjects such as sex and friends at a distance. Personae, whose usual job here is to invert values, replace the former we speaker. Sometimes by actualizing it, the loss supposedly experienced is shown to be preposterous, as in "Fame," where everyone is famous. In "Party" unreflected-upon desires are granted; they turn out to involve unconsidered consequences that catch us again. Only refusal saves the speaker. Overall, Laments darkens as it proceeds. The program fails. In Kafka-like movements, speakers hunger for what they can't have: meaning, permanance, independent selfhood. Still, they try for each. In "Caged," the speaker attempts to make captivity seem luxurious. "How it Was" contains writing like this:

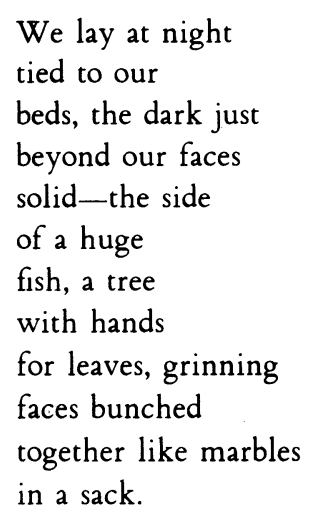

In "Lament for Moviegoers," a subject taken up before in "Bijou" and "Intermission" (TW), Rutsala courts his most dangerous foe, passivity, and comes out with more force: "As they say: / the only pleasure / is to look." 
This tone is developed in "Living," (TJB) this way: "No one tells you how it's done- / you are expected to know - / to, say, be able to get up every day." Which brings me to The Journey Begins: this volume also begins in a haze. The question is not why we have become as we are, or how we might escape, so much as what we are, the prerequisite to real rather than vicarious journeys. As we already know, the first such journey Rutsala has attempted has been into memory, childhood, ancestry. But The Journey Begins starts us on a series of journeys of persona and reflection. The most frequently used tool in the book is an odd way of seeing; where Rutsala might have used abstraction in The Window or type-personification in Laments, here he prefers metaphor. In "Investigations," we read "Silence wants voices, rooms long for guests," and later,

In rooms and halls each look says decide.

The smallest gesture hides a vast rhetoricconscience an old clipping you pull out time after time until it turns to powder.

One sequence, made up of "Unlocking the Door," "Quiet Streets," and "Thirst," focuses on a gentle desperation, underlined in "Thirst" by "we try,"-not to sleep, but to go out to others. The further we get into the book, the larger the gestures. "The Father," one of a group of persona poems, concerns a man trying to break free of the ruts of his daily life. In doing so, he thoroughly frightens himself. Earlier in the book, in "Other Lives," a speaker on a train imagines the people he passes so that they have, at most, a fleeting reality. But here he thinks at one point "he understands the men who turn errands into getaways / flying off for good on a loaf of bread," and that

The shotgun blast is their only music; the antidote of their disease is death, divided equally; the geometry of the family cancelled all at once.

Eventually he feels his responsibility. It comes to him as a sudden worry about the safety of his children. The poem ends in one of Rutsala's difficult water images:

He bends and touches them

pushes at blanket, strokes their heads, knowing he must live by touching, that his name and the names of those he touches are never knownno language stretches that far. They live. They still live.

$\mathrm{He}$ undresses in the dark and lies down with his wife and begins floating through darkness to the shallow glassy light of morning. 
In The Journey Begins Rutsala leaves the discursive for narrative. The poem that introduced me to his work, the title piece of the volume, tells of an ill-fated rescue. An overweight woman, who eats incessantly, has come to take her aged parents away with her. Rutsala's detail is so strong and convincing that even this improbable character acquires a rare human dignity.

So his daughter--forty-five, three hundred pounds-drove all night, losing count of flats, splashing water into steam on the radiator.

Even now as they load the car she eats leftovers.

Her hands always seem greasy, the skin around her mouth glistens and her lips shine as if she had just licked them before having a picture taken.

You were always such a pretty girl, her mother says. So pretty.

Rutsala's poetry is difficult because it requires loving attention in the face of few immediate rewards. Aside from metaphor, the language is calm, clear and plain. Motifs like the house and water imagery recur frequently. Much of the humor is of the sort that makes me nervous. And the mood, the avoidance of transcendence, the dogged, programmatic insistance on this world, as the speakers know it, invites only in the sense that it makes one less lonely to know that one's fears, anxieties and problems with meaning are not unique. The triumph of the poetry is located in the same realm: it gives expression, finding language for this area of our experience. Passivity is a danger, perhaps the central weakness that this poetry sometimes gives in to, but the existence of the poems, that they go on-not merely repeating-distinguishes them and gives proof positive of hope. The value of Rutsala's poetry lies in its refusal to pretend things are other than the way the poet sees them. It's not simply that he won't allow himself some of our more characteristic forms of dishonesty. His refusals and allegiances go further: no leaps of faith-beside that in poetry; no love-beside that for the losers, for the world he strives to touch, for the reader, as his clarity shows. Vern Rutsala's body of poems, beautifully made, full of courage, seems to say: no matter that you fail, it is time to start again. 